\title{
Students' Perceptions of Mathematical Physics E-Module on Multiple Integral Material
}

\author{
Astalini $^{*}$, Darmaji², Dwi Agus Kurniawan ${ }^{3}$, Diki Chen ${ }^{4}$ \\ 1,2,3,4 Physics Education Study Program, FKIP, Jambi University, Muaro Jambi, Indonesia
}

\section{A R T I C L E I N F O}

\section{Article history:}

Received April 06, 2021

Revised April 11, 2021

Accepted July 11, 2021

Available online November 25, 2021

Kata Kunci:

Persepsi, E-modul, Fisika Matematika

Keywords:

Perception, E-module, Mathematics of physics

DOI:

https://dx.doi.org/10.23887/jet.v5i4.336 00

\begin{abstract}
A B S T R A K
Fisika Matematika sering dianggap mata kuliah yang sangat sulit untuk dipelajari, salah satu alasan yang membuat hal tersebut terjadi ialah kurangnya media pembelajaran yang mendukung mahasiswa. Selain itu, media yang sudah ada kebanyakan berbahasa asing sehingga dalam hal ini diperlukan sebuah media pembelajaran berbahasa indonesia, yaitu e-modul fisika matematika pada materi integral ganda. Penelitian ini bertujuan untuk melihat level persepsi mahasiswa terhadap e-modul fisika matematika materi integral ganda yang sudah dibuat. Pendekataan penelitian ini menggunakan mixed method dengan model explanatory. Teknik pengambilan sampel pada peneitian ini ialah purposive sampling dengan subjek penelitian 68 mahasiswa aktif pendidikan fisika yang mengontrak mata kuliah Fisika Matematika. Instrumen yang digunakan dalam penelitian ini berupa angket persepsi mahasiswa berjumlah 15 petanyaan dan lembar wawancara sebanyak 10 pertanyaan. Analisis data yang digunakan pada penelitian ini ialah statistik deskriptif. Hasil persepsi mahasiswa pendidikan fisika terhadap e-modul fisika matematika materi interal ganda dikategorikan baik dengan presentase 66,17\% dan dikategorikan sangat baik dengan presentase 33,83\%. Dari hasil dapat diketahui bahwa e-modul fisika matematika pada materi integral ganda dapat mendukung proses pembelajaran dan meningkatkan motivasi mahasiswa.
\end{abstract}

\section{A B S T R A C T}

Mathematical physics is often considered a very difficult subject to study, one of the reasons that makes this happen is the lack of learning media that supports students. In addition, most of the existing media are in foreign languages, so in this case we need an Indonesian language learning media, namely the mathematical physics e-module on dual integral material. This study aims to see the level of students' perceptions of the mathematics physics e-module on the dual integral material that has been made. The approach of this study uses a mixed method with an explanatory model. The sampling technique in this research was purposive sampling with 68 research subjects active physics education students who contracted Mathematics Physics courses. The instrument used in this study was a student perception questionnaire with 15 questions and an interview sheet with 10 questions.. The data analysis used in this research is descriptive statistics. The results of physics education students' perceptions of the mathematics physics e-module of multiple internal material were categorized as good with a percentage of $66.17 \%$ and in the very good category with a percentage of $33.83 \%$. From the results it can be seen that the mathematical physics e-module on dual integral material can support the learning process and increase student motivation.

This is an open access article under the CC BY-SA license.

Copyright @ 2021 by Author. Published by Universitas Pendidikan Ganesha.

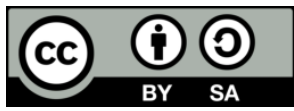

\section{INTRODUCTION}

Technology in the 21st century has advanced in various sectors of everyday human life (Bervell \& Umar, 2017; Lase, 2019; Ong et al., 2020; Weng et al., 2019). In view of this, technology also has a large and significant share in the development of education (Raja \& Nagasubramani, 2018; Buchanan et al., 2019). Educational technology in helping students and educators can be said to be a very effective partner or tool (Bingimlas, 2009; Putrawangsa \& Hasanah, 2018; Hidayat et al., 2020) Aids used in the field of education have a function as a presentation of information for teachers and learning resources for students (Astashova et al., 2017; Muhametjanova \& Akmatbekova, 2019) In presenting information, there are various forms, one of which is electronic based, one of the electronic based material presentations that educators often use is electronic modules (e-modules). The use of learning media is believed to be able to help students in learning especially in mathematical physics lessons. Mathematical physics as the name suggests contains analytical equations 
regarding theoretical physics which are solved using mathematical equations (Tandililing, 2015; Gunada et al., 2017; Saputri et al., 2016). The results of several previous studies from several experts show that most college students experience difficulties and also get unsatisfactory grades (Ellianawati \& Wahyuni, 2012; Marisda, 2019). Most of the students thought that the media used, namely the Mathematics Physics book, was still in a foreign language, so that in this case students had difficulties both in terms of explaining the material and analyzing the equations contained in the source material. In addition, previous research stated that examples of application and discussion in the textbook of mathematical physics, namely Mathematical Methods in the Physical Sciences written by Mary L. Boas, which are 839 pages thick, are still lacking (Ellianawati \& Wahyuni, 2012). As stated by This indicates the need for mathematical physics teaching materials which contain more examples of questions and their discussion. So in this case, the researcher wants to see the students' perceptions of the mathematical physics e-module on the dual integral material.

Science is one of the studies that has a complex and abstract nature, in this case it requires high teacher skills in teaching and the selection of learning media (Finley et al., 1982; Furner \& Kumar, 2007; Taştan et al., 2018). One of the objectives of learning science is to introduce students to scientific concepts in everyday life (Muakhirin, 2014; Suryaningsih, 2017; Faize et al., 2018). The concepts in science learning do not necessarily come from the results and data analysis but come from the human brain that has thoughts through imagination and the curiosity of scientists (Muna et al., 2017; Gunawan et al., 2018; Sumarni et al, 2019). In science itself, it can be divided into several fields that have different studies, one of which is Physics. Physics is one of the scientific studies that studies how the influence or a complex phenomenon is then used as a concept or theory (Trianggono, 2017; Wartono et al., 2018). With physics learning, phenomena that occur through observation are not only observed but also look for problem solving and solutions that are drawn from the human mind (Lesmono et al., 2012; Darmaji et al., 2019; Huseby \& Bungum, 2019). In education, physics has various applications that are very important in advancing students and educators themselves (Wambugu \& Changeiywo, 2008; Shishigu et al., 2018). Specifically, physics has various other fields of study that specifically discuss a material, one of the fields of study of physics that is specifically taught in higher education is Mathematical Physics. In addition to this, the attractiveness of learning is also a very important key in helping to understand material that is quite difficult, the attractiveness of learning can be found in the use of interactive e-modules that are integrated with the Mathematics Physics course, folding integral material.

Electronic-based modules or better known as e-modules are innovative learning media whose access is integrated with software supported by e-module access applications (Priatna et al., 2017; Matsun et al., 2019; Linda et al., 2018). The completeness of the contents of the e-module is in the form of a synthesis of issues and materials whose presentation can be viewed using electronic goods (Gavrilenko, 2018; Pratono et al., 2018; Elvarita et al., 2020). A good e-module can be arranged based on students' abilities and has a systematic order of presentation (Jaenudin et al., 2017; Laili et al., 2019; Afriyanti et al., 2021). According to several previous studies from experts (Istuningsih et al., 2018; Sitorus et al., 2019; Hadiyanti et al., 2021) it was found that the use of e-modules can help students effectively absorb the material taught by educators. The material used in the e-module can be selected according to the needs of the educator, in science learning itself this e-module is very useful as a simplification of material, some of which have complex and abstract properties.

The e-module being developed is an e-module that is integrated with Mathematical Physics I material, namely Multiple Integral. Mathematical physics is a combination of physics and mathematics subjects. Mathematical physics aims to make students have the ability to formulate various physics processes into mathematical statements and be able to solve them analytically, quantitatively, and predictive based on the reasoning model formulated (Tandililing, 2015; Saputri et al., 2016; Gunada et al., 2017). Mathematical physics is often considered difficult to learn due to several factors, one of which is the learning media used in foreign languages and the use of words that are too high for students. The use of learning media certainly cannot be arbitrary, good learning media will have a direct impact on student achievement in class. To see the quality of a product, namely the e-module created, it is necessary to measure perceptions. The perception is a process of receiving a stimulus from the five senses, then processed and concluded so as to produce a stimulus that will be accepted by other individuals (Erdemir \& EKŞİ, 2019; Yodha et al., 2019). Perception is defined as a view or understanding, namely how individuals perceive or interpret certain objects (Kusuma \& Luffiany, 2018; Yunita \& Maisarah, 2020). Perception can be divided into two, namely negative perception and positive perception. The findings of previous research also stated that e-modules can help students in learning so that they can improve student learning outcomes (Asrial et al., 2020; Fonda \& Sumargiyani, 2018; Velan et al., 2015). Based on the description stated, the purpose of this study is to analyze the level of student perception after using the e-module Mathematics Physics multiple integral material. 


\section{METHOD}

This study used a mixed method with an explanatory model, the variables in the form of students' perceptions of the mathematical physics e-module on the dual integral material. Mixed method explanatory model is a mixture of research methods with quantitative and qualitative research sequentially (Tanti et al., 2021). In the first stage, quantitative data collection was carried out followed by the second stage, namely, qualitative data collection. In quantitative research, the sample used is analyzed systematically and the results are in the form of numbers. Collecting quantitative data using a survey method which is intended to determine in general the characteristics of the sample under study (Tanti et al., 2021). Strengthening and completing quantitative data can be done using qualitative data. This qualitative data is obtained from the results of the analysis of the questionnaire which is equipped with an interview to describe the data. The sampling technique in this study is using purposive sampling technique. Purposive sampling is a sampling technique from data sources with certain considerations (Rosdianto et al., 2017). Sampling in this study was based on seeing the level of student perceptions of the mathematical physics e-module. The research was conducted online using google form as a data collection tool. The subjects of this study were 68 active physics education students who contracted mathematical physics courses. The perception questionnaire used is 15 statements and for the interview sheets as many as 5 statements, the data collection instrument grid can be seen in Table 1 .

Table 1. Student Perception Questionnaire Instrument Grid

\begin{tabular}{cl}
\hline Assessment Indicators & \multicolumn{1}{c}{ Rated aspect } \\
\hline & Text clarity \\
& Multimedia size suitability \\
& The clarity of the color and shape of the image \\
& Good multimedia display quality \\
& Multimedia that is presented is attractive \\
& The material is easy to understand \\
& The order of the material is clear \\
& The sentences used are simple and easy to understand \\
& The language used is communicative \\
& Sample suitability with material \\
& The suitability of multimedia with the material \\
& Ease of use of modules \\
Bresentation of Material in the E-Module & Media can help students understand the material \\
& Interest in using modul \\
& Increased motivation to learn \\
\hline
\end{tabular}

Student perception data of the mathematics physics e-module on multiple integral material were collected using a Likert scale with the following scores; 4 (strongly agree), 3 (agree), 2 (disagree), and 1 (strongly disagree). The level of students' perceptions of the e-module mathematics physics material multiple intervals, is used to determine the level of each categorized student perception, namely; Very good, good, bad, and very bad. By using quantitative descriptive, several values are obtained, namely; mean, median, mode, range, standard deviation, maximum and minimum. To get this value, SPSS 22 is used as a data processing tool.

\section{RESULT AND DISCUSSION}

Result

The results of the student's perception data on the e-module of mathematical physics on dual integral material. Based on the results of data analysis, shows that of the 68 respondents, a minimum value of 45.00 and a maximum value of 58.00 is obtained and with an average (mean) value of 50.53, a mode of 55.00, and a standard deviation. equal to 3.51. To show students' perceptions according to their categories, an interval score is needed to differentiate them. The level or level of student perceptions of e-modules on multiple integral material can be seen in Table 2 .

Tabel 2. The score ranges for the quantitative criteria for the perception questionnaire

\begin{tabular}{ccccc}
\hline No & Score Interval & Student Perception Level & F & $(\boldsymbol{\%})$ \\
\hline 1 & $48,76-60,00$ & Very good & 45 & 66,17 \\
2 & $37,51-48,75$ & Good & 23 & 33,83 \\
3 & $26,26-37,50$ & Bad & 0 & 0 \\
4 & $15,00-26,25$ & Very Bad & 0 & 0 \\
\hline \multicolumn{7}{r}{ Total } & & 68 & 100 \\
\hline
\end{tabular}


The results of the perception questionnaire from 68 students who contracted the mathematics physics course showed that students had a good perception of the products made by researchers. Good perceptions certainly have an impact on the quality of the products made. These results indicate that the use of mathematical physics e-module with dual integral material can support the learning process as well as a good complementary source of learning for students, especially those contracting Mathematics Physics courses. For the results of the interview, it was found that most of the students answered positive choices with a variety of different reasons. In the first question, "Is the use of e-modules in learning a good idea", one respondent answered "Yes, because it can be used anytime and anywhere". Meanwhile, other respondents answered "Yes, because learning can be interesting". In the second question, "Do you agree that the use of e-modules can help you study anywhere and anytime? Many respondents answered" Yes, because it can be easily opened on a smartphone anytime and anywhere ". In the third question, namely "Is learning through e-module media interesting ?, most students answered" Yes, because in the e-module there are videos, images and animations ". In the fourth question "Can learning using e-modules increase your learning motivation ?, students answered" Yes, because the more we know ". And in the last question, "Is using e-module learning flexible and clear ?, students answered" Yes, emodule learning is very easy to understand ".

\section{Discussion}

With the e-module of mathematical physics, this dual integral material indirectly makes one of the learning problems resolved. Learning mathematics physics contains analytical descriptions, so that most students consider learning very difficult to understand (Kowiyah \& Mulyawati, 2018; Muhtadi et al., 2018). However, with this e-module, students no longer need to translate material in English and students will quickly understand learning because difficult material has been shortened and explained using simple words. In addition, the longterm impact of using this e-module is that it can help students to graduate from the Mathematical Physics course which is notoriously difficult and often makes most students repeat the course. E-modules that have good value and quality can be shown from the level of good student perceptions (Pathoni et al., 2017; Syahrial et al., 2019). An e-module that has good quality can significantly help students in their studies in Physics education. Then in terms of language, the e-module used is in Indonesian, making it very easy for students to discuss and answer analytical questions. Misinterpretation of words can also be overcome effectively, because for this module the language has been simplified and is equipped with video discussions on topics that are a little difficult. In addition to short-term effects, this e-module has long-term effects for students. Physics education students whose output produces educators certainly need a good pedagogic aspect. With this e-module, students can improve their pedagogical aspects as prospective physics teachers who are required to have analytical understanding and critical thinking. The pedagogic aspect itself is a teacher's ability and competence on how to manage and master the classroom (Gluzman et al., 2018; Machaba, 2018). Previous research by experts shows that this aspect is very crucial in educating and teaching in the classroom, teachers with high pedagogical aspects mostly enjoy and are liked by students (Moh'd et al., 2021; Pöntinen \& Räty-Záborszky, 2020). These aspects cannot be instantaneously formed, but need to be trained and accustomed to every day. One of the things that helps improve the pedagogic aspect, especially for prospective physics teachers, is to use e-modules that are integrated with analytical material.

Then for professional competence refers to the ability of a teacher to succeed in learning in class (Fitriani et al., 2017; Jamin, 2018). Professional competence is the ability to master subjects with the help of media accompanied by a sense of responsibility (Kartini et al, 2020; Supriyanto et al., 2020; Uerz, et al, 2018). With this competence, it will lead to the creation of a comfortable work environment. The relationship between professional competence and student perceptions of teaching materials is that it can facilitate students in mastering subject matter, especially physics. If a prospective physics teacher has fully mastered the material, then class learning will be comfortable and clear. In addition, for the lecturers themselves, this perception measurement is very important to see what methods are appropriate in classroom learning (Mashuri, 2017; Widyastuti et al., 2017). On the other hand, the media used, namely e-modules, can be used as a complementary source for lecturers in teaching in the classroom. The language used is also Indonesian, making it easier for lecturers to understand and explain it to students. In this case, lecturers do not need to waste time in interpreting foreign languages that some are difficult to understand.

No research is perfect in all aspects. In this study, we only looked at the level of students' perceptions and responses after using the Mathematics Physics e-module. This study is different from research from examines the relationship between perceptions of one class and another (Serevina et al., 2018; Darmaji et al., 2019; Asrial et al., 2020). This is because the sample used is not enough and only 68 people. Previous research from also used several variables so that it is more varied than research conducted by researchers (Haviz et al., 2020; Rizal et al., 2020; Rusydiyah et al., 2021). However, this research has the advantage that it uses qualitative data in the form of interviews which is not present in the previous research that has been described. Based on 
these shortcomings, the researcher suggests for further research to add several variables, add more samples, and further develop data analysis such as using the ANOVA test, correlation test, and others.

\section{CONCLUSION}

The results obtained from the study showed that e-module learning received a positive response from students, this was also supported by the results of interviews, which were mostly satisfied with the e-modules that had been made. This positive perception has a direct impact on the experience of both students and lecturers in learning. For students, having a good experience can certainly solve problems related to difficult, abstract, or analytical materials. As for lecturers, this can help realize learning objectives according to the design that has been made.

\section{REFERENCES}

Afriyanti, M., Suyatna, A., \& Viyanti. (2021). Design of e-modules to stimulate HOTS on static fluid materials with the STEM approach. Journal of Physics: Conference Series, 1788(1). https://doi.org/10.1088/1742-6596/1788/1/012032.

Asrial, Syahrial, Maison, Kurniawan, D. A., \& Piyana, S. O. (2020). Ethnoconstructivism E-Module to Improve Perception, Interest, and Motivation of Students in Class V Elementary School. JPI (Jurnal Pendidikan Indonesia), 9(1), 30-41. https://doi.org/10.23887/jpi-undiksha.v9i1.19222.

Astashova, N. A., Bondreva, S. K., \& Malkina, O. V. (2017). Strategic Guidelines Of The Educational Interactive Environment as a Basis to Develop The Axiosphere of a Future Teacher. Journal of $\begin{array}{llll}\text { Fundamental and } \quad \text { Applied } & \text { Sciences, } & \text { 9(7), } & 1392-1418 .\end{array}$ https://www.ajol.info/index.php/jfas/article/view/169275.

Bervell, B., \& Umar, I. N. (2017). Validation of the UTAUT model: Re-considering non-linear relationships of exogeneous variables in higher education technology acceptance research. Eurasia Journal of Mathematics, Science and Technology Education, 13(10), 6471-6490. https://doi.org/10.12973/ejmste/78076.

Bingimlas, K. A. (2009). Barriers to the successful integration of ICT in teaching and learning environments: A review of the literature. Eurasia Journal of Mathematics, Science and Technology Education, 5(3), 235-245. https://doi.org/10.12973/ejmste/75275.

Buchanan, J., Pressick-Kilborn, K., \& Maher, D. (2019). Promoting environmental education for primary schoolaged students using digital technologies. Eurasia Journal of Mathematics, Science and Technology Education, 15(2). https://doi.org/10.29333/ejmste/100639.

Darmaji, D., Kurniawan, D. A., \& Suryani, A. (2019). Effectiveness of Basic Physics II Practicum Guidelines Based On Science Process Skills. JIPF (Jurnal Ilmu Pendidikan Fisika), 4(1), 1. https://doi.org/10.26737/jipf.v4i1.693.

Ellianawati, \& Wahyuni, S. (2012). Pengembangan Bahan Ajar Fisika Matematika Berbasis Self Regulated Learning Sebagai Upaya Peningkatan Kemampuan Belajar Mandiri. Jurnal Pendidikan Fisika Indonesia, 8(1), 33-40. https://doi.org/10.15294/jpfi.v8i1.1992.

Elvarita, A., Iriani, T., \& Handoyo, S. S. (2020). Pengembangan Bahan Ajar Mekanika Tanah Berbasis E-Modul pada Program Studi Pendidikan Teknik Bangunan, Universitas Negeri Jakarta. Jurnal Pendidikan Teknik Sipil (JPenSil), 9(1), 1-7. https://doi.org/10.21009/jpensil.v9i1.11987.

Erdemir, N., \& EKŞİ, G. Y. (2019). The perceptions of student teachers about using an online learning environment 'Edmodo'in a 'flipped classroom.' SDU International Journal of Educational Studies, 6(2), 174-186. https://doi.org/10.33710/sduijes.638795.

Faize, F. A., Husain, W., \& Nisar, F. (2018). A critical review of scientific argumentation in science education. Eurasia Journal of Mathematics, Science and Technology Education, 14(1), 475-483. https://doi.org/10.12973/ejmste/80353.

Finley, F. N., Stewart, J., \& Yarroch, W. L. (1982). Teachers' perceptions of important and difficult science content. Science Education, 66(4), 531-538. https://doi.org/10.1002/sce.3730660404.

Fitriani, C., AR, M., \& Usman. (2017). Kompetensi Profesional Guru Dalam Pengelolaan Pembelajaran di MTs Muhammadiyah Banda Aceh. Jurnal Magister Administrasi Pendidikan, 5(2), 88-95. http://erepository.unsyiah.ac.id/JAP/article/view/8246.

Fonda, A., \& Sumargiyani, S. (2018). The Developing Math Electronic Module With Scientific Approach Using Kvisoft Flipbook Maker Pro For Xi Grade Of Senior High School Students. Infinity Journal, 7(2), 109122. https://doi.org/10.22460/infinity.v7i2.p109-122.

Furner, J. M., \& Kumar, D. D. (2007). The mathematics and science integration argument: A stand for teacher 
education. Eurasia Journal of Mathematics, Science and Technology Education, 3(3), 185-189. https://doi.org/10.12973/ejmste/75397.

Gavrilenko, N. (2018). Online model for teaching and learning the specialized translation. Eurasia Journal of Mathematics, Science and Technology Education, 14(6), 2711-2717. https://doi.org/10.29333/ejmste/85421.

Gluzman, N. A., Sibgatullina, T. V., Galushkin, A. A., \& Sharonov, I. A. (2018). Forming the basics of future mathematics teachers' professionalism by means of multimedia technologies. Eurasia Journal of Mathematics, Science and Technology Education, 14(5), 1621-1633. https://doi.org/10.29333/ejmste/85034.

Gunada, I. W., Rokhmat, J., Hikmawati, H., \& Kesipudin, K. (2017). Pengembangan Bahan Ajar Kompilasi Fisika Matematika Ii Pokok Bahasan Persamaaan Diferensial Untuk Meningkatkan Penalaran Matematis. Jurnal Pendidikan Fisika Dan Teknologi, 3(2), 216. https://doi.org/10.29303/jpft.v3i2.414.

Gunawan, B., Relmasira, S. C., \& Hardini, A. T. A. (2018). Penerapan Model Pembelajaran Projrct Basd Learning Untuk Meningkatkan Hasil Belajar IPA dan Kemampuan Berpikir Kritis Siswa Kelas SD. JTIEE, 2(1), 32-45. http://dx.doi.org/10.23887/jippg.v4i3.38185.

Hadiyanti, N. F. D., Hobri, Prihandoko, A. C., Susanto, Murtikusuma, R. P., Khasanah, N., \& Maharani, P. (2021). Development of mathematics e-module with STEM-collaborative project based learning to improve mathematical literacy ability of vocational high school students. Journal of Physics: Conference Series, 1839(1). https://doi.org/10.1088/1742-6596/1839/1/012031.

Haviz, M., Lufri, L., \& Maris, I. M. (2020). Assessing prospective biology teachers (PBTs) perceptions on thinking as a 21st century skill: A case study at Islamic University. Jurnal Pendidikan IPA Indonesia, 9(3), 319-329. https://doi.org/10.15294/jpii.v9i3.24077.

Hidayat, H., Mulyani, H., Nurhasanah, S. D., Khairunnisa, W., \& Sholihah, Z. (2020). Peranan Teknologi dan Media Pembelajaran Bagi Siswa Sekolah Dasar di Dalam Pembelajaran Pendidikan Kewarganegaraan. $\begin{array}{lllll}\text { JUnal Pendidikan } \quad \text { Kewarganegaraan } & \text { Undika, }\end{array}$ http://dx.doi.org/10.23887/jpku.v8i2.24759.

Huseby, A., \& Bungum, B. (2019). Observation in quantum physics: Challenges for upper secondary physics students in discussing electrons as waves. Physics Education, 54(6). https://doi.org/10.1088/13616552/ab3694

Istuningsih, W., Baedhowi, \& Bayu Sangka, K. (2018). The Effectiveness of Scientific Approach Using EModule Based on Learning Cycle 7E to Improve Students' Learning Outcome. International Journal of Educational Research Review, 3(3), 75-85. https://doi.org/10.24331/ijere.449313.

Jaenudin, A., Baedhowi, P., \& Murwaningsih, T. (2017). The Effectiveness of the E-Module of Economics Learning on Problem-Based Learning used to Improve Students' Learning Outcomes. 158(Ictte), 3036. https://doi.org/10.2991/ictte-17.2017.32.

Jamin, H. (2018). Upaya meningkatkan kompetensi profesional. Jurnal Pendidikan Dan Kebudayaan, 10(1), 175-186. https://ejournal.umm.ac.id/index.php/jkpp/article/download/11613/pdf/32156.

Kartini, D., Kristiawan, M., \& Fitria, H. (2020). The Influence of Principal's Leadership, Academic Supervision, and Professional Competence toward Teachers' Performance. International Journal of Progressive Sciences and Technologies (IJPSAT) ISSN: 2509-0119., 20 No. 1 A(April), 156-164. http://dx.doi.org/10.52155/ijpsat.v20.1.1730.

Kowiyah, \& Mulyawati, I. (2018). An analysis of primary school students' representational ability in mathematics based on gender perspective. Journal of Physics: Conference Series, 948(1). https://doi.org/10.1088/1742-6596/948/1/012016.

Laili, Ganefri, \& Usmeldi. (2019). Efektivitas Pengembangan E-Modul Project Based Learning pada Mata Pelajaran Instalasi Motor Listrik. Jurnal Ilmiah Pendidikan Dan Pembelajaran, 3(3). https://doi.org/10.23887/jipp.v3i3.21840.306-309.

Lase, D. (2019). Education and Industrial Revolution 4.0. Handayani Journal PGSD FIP Unimed, 10(1), 48-62. https://doi.org/10.24114/jh.v10i1.14138.

Lesmono, A. D., Wahyuni, S., \& Alfiana, R. D. N. (2012). Pengembangan Bahan Ajar Fisika Berupa Komik Pada Materi Cahaya Di SMP. Jurnal Pembelajaan Fisika, 1(1), 100-105. https://doi.org/10.19184/jpf.v1i1.23143.

Linda, R., Herdini, Sulistya, I., \& Putra, T. P. (2018). Interactive E-Module Development through Chemistry Magazine on Kvisoft Flipbook Maker Application for Chemistry Learning in Second Semester at Second Grade Senior High School. Journal of Science Learning, 2(1), 21-25. https://doi.org/10.17509/jsl.v2i1.12933.

Machaba, F. M. (2018). Pedagogical demands in mathematics and mathematical literacy: A case of mathematics and mathematical literacy teachers and facilitators. Eurasia Journal of Mathematics, Science and Technology Education, 14(1), 95-108. https://doi.org/10.12973/ejmste/78243. 
Marisda, D. H. (2019). The Effect of Task-Based Collaborative Learning on Students' Mathematical Physics Learning Outcomes at Universitas Muhammadiyah Makassar. Jurnal Pendidikan Fisika, 7(2), 140-150. https://doi.org/10.26618/jpf.v7i2.2038.

Mashuri, H. (2017). Persepsi Siswa Terhadap Pembelajaran Guru Pendidikan Jasmani Di Sma Muhammadiyah Kediri. Jurnal Pembelajaran Olaraga, 3(1), 1-10. https://doi.org/10.29407/js_unpgri.v3i1.681.

Matsun, Andrini, V. S., Maduretno, T. W., \& Yusro, A. C. (2019). Development of physics learning e-module based on local culture wisdom in Pontianak,West Kalimantan. Journal of Physics: Conference Series, 1381(1). https://doi.org/10.1088/1742-6596/1381/1/012045.

Moh'd, S. S., Uwamahoro, J., Joachim, N., \& Orodho, J. A. (2021). Assessing the Level of Secondary Mathematics Teachers' Pedagogical Content Knowledge. Eurasia Journal of Mathematics, Science and Technology Education, 17(6), em1970. https://doi.org/10.29333/ejmste/10883.

Muakhirin, B. (2014). Peningkatan Hasil Belajar IPA Melalui Pendekatan Pembelajaran Inkuiri Pada Siswa SD. Jurnal Ilmiah Guru, 5(01), 57. https://journal.uny.ac.id/index.php/cope/article/view/2933.

Muhametjanova, G., \& Akmatbekova, A. (2019). The web-based learning environment in general physics course in a public university in Kyrgyzstan. Eurasia Journal of Mathematics, Science and Technology Education, 15(3). https://doi.org/10.29333/ejmste/100409.

Muhtadi, D., Wahyudin, Kartasasmita, B. G., \& Prahmana, R. C. I. (2018). The Integration of technology in teaching mathematics. Journal of Physics: Conference Series, 943(1), 1-9. https://doi.org/10.1088/1742-6596/943/1/012020.

Muna, I., Rahayu, S., \& Marfu'ah, S. (2017). Pemahaman Hakikat Sains Dan Inkuiri Ilmiah Calon Guru Kimia. J-PEK (Jurnal Pembelajaran Kimia), 2(2), 15-22. https://doi.org/10.17977/um026v2i22017p015.

Ong, K. J., Chou, Y. C., Yang, D. Y., \& Lin, C. C. (2020). Creative drama in science education: The effects on situational interest, career interest, and science-related attitudes of science majors and non-science majors. Eurasia Journal of Mathematics, Science and Technology Education, 16(4). https://doi.org/10.29333/ejmste/115296.

Pathoni, H., Jufrida, Saputri, I., \& Sari, W. (2017). Persepsi Mahasiswa Terhadap E-modul Pembelajaran Mata Kuliah Fisika Atom dan Inti. Jurnal Eksakta Pendidikan (JEP), 1(1), 55-62. https://doi.org/10.24036/jep/vol1-iss1/35.

Pöntinen, S., \& Räty-Záborszky, S. (2020). Pedagogical aspects to support students' evolving digital competence at school. European Early Childhood Education Research Journal, 28(2), 182-196. https://doi.org/10.1080/1350293X.2020.1735736.

Pratono, A., Sumarti, S. S., \& Wijayati, N. (2018). Contribution of Assisted Inquiry Model of E-Module to Students Science Process Skill. Journal of Innovative Science Education, 7(1), 62-68. https://doi.org/10.15294/jise.v7i1.20633.

Priatna, I. K., Putrama, I. M., \& Divayana, D. G. H. (2017). Pengembangan E-Modul Berbasis Model Pembelajaran Project Based Learning Pada Mata Pelajaran Videografi untuk Siswa Kelas X Desain Komunikasi Visual di SMK Negeri 1 Sukasada. Jurnal Nasional Pendidikan Teknik Informatika (JANAPATI), 6(1), 70. https://doi.org/10.23887/janapati.v6i1.9931.

Putrawangsa, S., \& Hasanah, U. (2018). Integrasi Teknologi Digital Dalam Pembelajaran Di Era Industri 4.0. Jurnal Tatsqif, 16(1), 42-54. https://doi.org/10.20414/jtq.v16i1.203.

Raja, R., \& Nagasubramani, P. C. (2018). Impact of modern technology in education. Journal of Applied and Advanced Research, 3(S1), 33. https://doi.org/10.21839/jaar.2018.v3is1.165.

Rizal, R., Rusdiana, D., Setiawan, W., \& Siahaan, P. (2020). Students perception of learning management system supported smartphone: Satisfaction analysis in online physics learning. Jurnal Pendidikan IPA Indonesia, 9(4), 600-610. https://doi.org/10.15294/jpii.v9i4.25363.

Rosdianto, H., Murdiani, E., \& Hendra. (2017). Implementasi Model Pembelajaran POE (Predict Observe Explain) Untuk Meningkatkan Pemahaman Konsep Siswa Pada Materi Hukum Newton. Jurnal Pendidikan Fisika, 6(1), 55-59. https://doi.org/https://doi.org/10.29103/ijevs.v1i7.1757.

Rusydiyah, E. F., Indrawati, D., Jazil, S., Susilawati, \& Gusniwati. (2021). Stem learning environment: Perceptions and implementation skills in prospective science teachers. Jurnal Pendidikan IPA Indonesia, 10(1), 138-148. https://doi.org/10.15294/jpii.v10i1.28303.

Saputri, D. F., Fadilah, S., \& Wahyudi. (2016). Efektifitas Penggunaan Buku Ajar Fisika Matematika Berbasis Inkuiri dalam Perkuliahan Fisika Matematika. Jurnal Penelitian \& Pengembangan Pendidikan Fisika, 2(2), 7-14. https://doi.org/https://doi.org/10.21009/1.02202.

Serevina, V., Sunaryo, Raihanati, Astra, I. M., \& Sari, I. J. (2018). Development of E-Module Based on Problem Based Learning ( PBL ) on Heat and Temperature to Improve Student's Science Process Skill. The Turkish Online Journal of Education Technology, 17(3), 26-36. https://eric.ed.gov/?id=EJ1184205.

Shishigu, A., Hailu, A., \& Anibo, Z. (2018). Problem-based learning and conceptual understanding of college female students in physics. Eurasia Journal of Mathematics, Science and Technology Education, 14(1), 
145-154. https://doi.org/10.12973/ejmste/78035.

Sitorus, D. S., Suwandari, \& Kristiani. (2019). The Effectiveness of Accounting E-Module Integrated with Character Value to Improve Students Learning Outcomes and Honesty. Cakrawala Pendidikan, 38(1120-129). https://doi.org/10.21831/cp.v38i1.20878

Sumarni, W; Wijayati, N., \& Supanti, S. (2019). Kemampuan Kognitif dan Berpikir Kreatif Siswa Melalui Pembelajaran Berbasis Proyek Berpendekatan STEM. Jurnal Pembelajaran Kimia, 4(1), 18-30. http://dx.doi.org/10.17977/um026v4i12019p018.

Supriyanto, A., Hartini, S., Irdasari, W. N., Miftahul, A., Oktapiana, S., \& Mumpuni, S. D. (2020). Teacher professional quality: Counselling services with technology in Pandemic Covid-19. Counsellia: Jurnal Bimbingan Dan Konseling, 10(2), 176. https://doi.org/10.25273/counsellia.v10i2.7768.

Suryaningsih, Y. (2017). Pembelajaran Berbasis Praktikum Sebagai Sarana Siswa Untuk Berlatih Menerapkan Keterampilan Proses Sains Dalam Materi Biologi. Jurnal Bio Education, 2(2), $49-57$. http://dx.doi.org/10.31949/be.v2i2.759.

Syahrial, Asrial, Kurniawan, D. A., \& Piyana, S. O. (2019). E-Modul Etnokontruktivisme: Implementasi Pada Kelas V Sekolah Dasar Ditinjau Dari Persepsi, Minat Dan Motivasi. JTP - Jurnal Teknologi Pendidikan, 21(2), 165-177. https://doi.org/10.21009/jtp.v21i2.11030.

Tandililing, E. (2015). Pengembangan Mathematical Maple Berbasis Kooperatif Think-Share untuk Meningkatkan Kemampuan Representasi Matematis Mahasiswa dan Kualitas Perkuliahan Fisika Matematik. Jurnal Pendidikan Matematika Dan IPA, 6(1), $45-56$. https://doi.org/http://dx.doi.org/10.26418/jpmipa.v6i1.16223.

Tanti, Kurniawan, D. A., Sukarni, W., Erika, \& Hoyi, R. (2021). Description of Students Response Toward the Implementation of Problem-Based Learning Model in Physics Learning. Jurnal Ilmu Pendidikan Fisika, 6(1), 30-38. https://doi.org/http://dx.doi.org/10.26737/jipf.v6i1.1787.

Taştan, S. B., Davoudi, S. M. M., Masalimova, A. R., Bersanov, A. S., Kurbanov, R. A., Boiarchuk, A. V., \& Pavlushin, A. A. (2018). The impacts of teacher's efficacy and motivation on student's academic achievement in science education among secondary and high school students. Eurasia Journal of Mathematics, Science and Technology Education, 14(6), 2353-2366. https://doi.org/10.29333/ejmste/89579.

Trianggono, M. M. (2017). Analisis Kausalitas Pemahaman Konsep Dengan Kemampuan Berpikir Kreatif Siswa Pada Pemecahan Masalah Fisika. Jurnal Pendidikan Fisika Dan Keilmuan (JPFK), 3(1), 1. https://doi.org/10.25273/jpfk.v3i1.874.

Uerz, D., Volman, M., \& Kral, M. (2018). Teacher educators' competences in fostering student teachers' proficiency in teaching and learning with technology: An overview of relevant research literature. Teaching and Teacher Education, 70, 12-23. https://doi.org/10.1016/j.tate.2017.11.005.

Velan, G. M., Goergen, S. K., Grimm, J., \& Shulruf, B. (2015). Impact of Interactive e-Learning Modules on Appropriateness of Imaging Referrals: A Multicenter, Randomized, Crossover Study. Journal of the American College of Radiology, 12(11). https://doi.org/10.1016/j.jacr.2015.06.026.

Wambugu, P. W., \& Changeiywo, J. M. (2008). Effects of mastery learning approach on secondary school students' physics achievement. Eurasia Journal of Mathematics, Science and Technology Education, 4(3), 293-302. https://doi.org/10.12973/ejmste/75352.

Wartono, W., Hudha, M. N., \& Batlolona, J. R. (2018). How are the physics critical thinking skills of the students taught by using inquiry-discovery through empirical and theorethical overview? Eurasia Journal of Mathematics, Science and Technology Education, 14(2), 691-697. https://doi.org/10.12973/ejmste/80632.

Weng, F., Ho, H. J., Yang, R. J., \& Weng, C. H. (2019). The influence of learning style on learning attitude with multimedia teaching materials. Eurasia Journal of Mathematics, Science and Technology Education, 15(1), 1-9. https://doi.org/10.29333/ejmste/100389.

Widyastuti, N., Widiyaningrum, P., \& Lisdiana. (2017). Analisis kompetensi guru biologi berdasarkan persepsi siswa SMA di kota Semarang. Journal of Innovative Science Education, 6(2), 212-226. https://doi.org/10.15294/jise.v6i2.15535.

Yodha, S. A., Abidin, Z., \& Adi, E. P. (2019). Persepsi Mahasiswa Terhadap Pelaksanaan E-Learning dalam Mata Kuliah Manajemen Sistem Informasi Mahasiswa Jurusan Teknologi Pendidikan Universitas Negeri Malang. Jurnal Kajian Teknologi Pendidikan, 2(3), 181-187. https://doi.org/http://dx.doi.org/10.17977/um038v2i32019p181.

Yunita, W., \& Maisarah, I. (2020). Students ' Perception On Learning Language At The Graduate Program OF English Education Amids The Covid 19 Pandemic. Linguists: Journal of Linguistics and Language Teaching, 2069(6), 107-120. https://doi.org/http://dx.doi.org/10.29300/ling.v6i2.3718. 